\title{
O NATIVO RELATIVO
}

\author{
Eduardo Viveiros de Castro
}

O ser humano, tal como o imaginamos, não existe.

Nelson Rodrigues

As páginas a seguir foram adaptadas do arrazoado introdutório a um livro em preparação, onde desenvolvo análises etnográficas anteriormente esboçadas. A principal delas foi um artigo publicado em M ana, "Os Pronomes Cosmológicos e o Perspectivismo A meríndio" (Viveiros de Castro 1996), cujos pressupostos metateóricos, digamos assim, são agora explicitados. Embora o presente texto possa ser lido sem nenhuma familiaridade prévia com o artigo de 1996, o leitor deve ter em mente que as referências a noções como 'perspectiva' e 'ponto de vista', bem como à idéia de um 'pensamento indígena', remetem àquele trabalho.

\section{As regras do jogo}

O 'antropólogo' é alguém que discorre sobre o discurso de um 'nativo'. O nativo não precisa ser especialmente selvagem, ou tradicionalista, tampouco natural do lugar onde o antropólogo o encontra; o antropólogo não carece ser excessivamente civilizado, ou modernista, sequer estrangeiro ao povo sobre o qual discorre. Os discursos, o do antropólogo e sobretudo o do nativo, não são forçosamente textos: são quaisquer práticas de sentido․ O essencial é que o discurso do antropólogo (o ‘observador') estabeleça uma certa relação com o discurso do nativo (o 'observado'). Essa relação é uma relação de sentido, ou, como se diz quando o primeiro discurso pretende à Ciência, uma relação de conhecimento. M as o conhecimento antropológico é imediatamente uma relação social, pois é o efeito das relações que constituem reciprocamente o sujeito que conhece e o sujeito que ele conhece, e a causa de uma transforma- 
ção (toda relação é uma transformação) na constituição relacional de ambos².

Essa (meta)relação não é de identidade: o antropólogo sempre diz, e portanto faz, outra coisa que o nativo, mesmo que pretenda não fazer mais que redizer 'textualmente' o discurso deste, ou que tente dialogar - noção duvidosa - com ele. Tal diferença é o efeito de conhecimento do discurso do antropólogo, a relação entre o sentido de seu discurso e o sentido do discurso do nativo3.

A alteridade discursiva se apóia, está claro, em um pressuposto de semelhança. $O$ antropólogo e o nativo são entidades de mesma espécie e condição: são ambos humanos, e estão ambos instalados em suas culturas respectivas, que podem, eventualmente, ser a mesma. M as é aqui que o jogo começa a ficar interessante, ou mel hor, estranho. Ainda quando antropólogo e nativo compartilham a mesma cultura, a relação de sentido entre os dois discursos diferencia tal comunidade: a relação do antropólogo com sua cultura e a do nativo com a dele não é exatamente a mesma. O que faz do nativo um nativo é a pressuposição, por parte do antropólogo, de que a relação do primeiro com sua cultura é natural, isto é, intrínseca e espontânea, e, se possível, não reflexiva; melhor ainda se for inconsciente. $\mathrm{O}$ nativo exprime sua cultura em seu discurso; o antropólogo também, mas, se ele pretende ser outra coisa que um nativo, deve poder exprimir sua cultura culturalmente, isto é, reflexiva, condicional e conscientemente. Sua cultura se acha contida, nas duas acepções da palavra, na relação de sentido que seu discurso estabelece com o discurso do nativo. J á o discurso do nativo, este está contido univocamente, encerrado em sua própria cultura. $\mathrm{O}$ antropólogo usa necessariamente sua cultura; o nativo é suficientemente usado pela sua.

Tal diferença, é ocioso lembrar, não reside na assim chamada natureza das coisas; ela é própria do jogo de linguagem que vamos descrevendo, e define as personagens designadas (arbitrariamente no masculino) como 'o antropólogo' e 'o nativo'. Vejamos mais algumas regras desse jogo.

A idéia antropológica de cultura coloca o antropólogo em posição de igualdade com o nativo, ao implicar que todo conhecimento antropológico de outra cultura é culturalmente mediado. Tal igualdade é, porém, em primeira instância, simplesmente empírica ou de fato: ela diz respeito à condição cultural comum (no sentido de genérica) do antropólogo e do nativo. A relação diferencial do antropólogo e o nativo com suas culturas respectivas, e portanto com suas culturas recíprocas, é de tal ordem que a igualdade de fato não implica uma igualdade de direito - uma igual- 
dade no plano do conhecimento. O antropólogo tem usualmente uma vantagem epistemológica sobre o nativo. $\mathrm{O}$ discurso do primeiro não se acha situado no mesmo plano que o discurso do segundo: o sentido que 0 antropólogo estabelece depende do sentido nativo, mas é ele quem detém o sentido desse sentido - ele quem explica e interpreta, traduz e introduz, textualiza e contextualiza, justifica e significa esse sentido. A matriz relacional do discurso antropológico é hilemórfica: o sentido do antropólogo é forma; o do nativo, matéria. O discurso do nativo não detém o sentido de seu próprio sentido. De fato, como diria Geertz, somos todos nativos; mas de direito, uns sempre são mais nativos que outros.

Este artigo propõe as perguntas seguintes. O que acontece se recusarmos ao discurso do antropólogo sua vantagem estratégica sobre o discurso do nativo? O que se passa quando o discurso do nativo funciona, dentro do discurso do antropólogo, de modo a produzir reciprocamente um efeito de conhecimento sobre esse discurso? Quando a forma intrínseca à matéria do primeiro modifica a matéria implícita na forma do segundo? Tradutor, traidor, diz-se; mas o que acontece se o tradutor decidir trair sua própria língua? O que sucede se, insatisfeitos com a mera igualdade passiva, ou de fato, entre os sujeitos desses discursos, reivindicarmos uma igualdade ativa, ou de direito, entre os discursos eles mesmos? Se a disparidade entre os sentidos do antropólogo e do nativo, longe de neutralizada por tal equivalência, for internalizada, introduzida em ambos os discursos, e assim potencializada? Se, em lugar de admitir complacentemente que somos todos nativos, levarmos às últimas, ou devidas, conseqüências a aposta oposta - que somos todos 'antropólogos' (Wagner 1981:36), e não uns mais antropólogos que os outros, mas apenas cada um a seu modo, isto é, de modos muito diferentes? O que muda, em suma, quando a antropologia é tomada como uma prática de sentido em continuidade epistêmica com as práticas sobre as quais discorre, como equivalente a elas? Isto é, quando aplicamos a noção de "antropologia simétrica" (Latour 1991) à antropologia ela própria, não para fulminá-la por colonialista, exorcizar seu exotismo, minar seu campo intelectual, mas para fazê-la dizer outra coisa? Outra coisa não apenas que o discurso do nativo, pois isso é o que a antropologia não pode deixar de fazer, mas outra que o discurso, em geral sussurrado, que o antropólogo enuncia sobre si mesmo, ao discorrer sobre o discurso do nativo?4

Se fizermos tudo isso, eu diria que estaremos fazendo o que sempre se chamou propriamente de 'antropologia', em vez de - por exemplo 'sociologia' ou 'psicologia'. Digo apenas diria, porque muito do que se fez e faz sob esse nome supõe, ao contrário, que o antropólogo é aquele 
que detém a posse eminente das razões que a razão do nativo desconhece. Ele tem a ciência das doses precisas de universalidade e particularidade contida no nativo, e das ilusões que este entretém a respeito de si próprio - ora manifestando sua cultura nativa acreditando manifestar a natureza humana (o nativo ideologiza sem saber), ora manifestando a natureza humana acreditando manifestar sua cultura nativa (ele cognitiza à revelia) ${ }^{5}$. A relação de conhecimento é aqui concebida como unilateral, a alteridade entre o sentido dos discursos do antropólogo e do nativo resolve-se em um englobamento. $O$ antropólogo conhece de jure o nativo, ainda que possa desconhecê-lo de facto. Quando se vai do nativo ao antropólogo, dá-se o contrário: ainda que ele conheça de facto o antropól ogo (freqüentemente melhor do que este o conhece), não o conhece de jure, pois o nativo não é, justamente, antropólogo como o antropólogo. A ciência do antropólogo é de outra ordem que a ciência do nativo, e precisa sê-lo: a condição de possibilidade da primeira é a deslegitimação das pretensões da segunda, seu "epistemocídio", no forte dizer de Bob Scholte (1984:964). O conhecimento por parte do sujeito exige o desconhecimento por parte do objeto.

M as não é realmente preciso fazer um drama a respeito disso. Como atesta a história da disciplina, esse jogo discursivo, com tais regras desiguais, disse muita coisa instrutiva sobre os nativos. A experiência proposta no presente artigo, entretanto, consiste precisamente em recusá-lo. Não porque tal jogo produza resultados objetivamente falsos, isto é, represente de modo errôneo a natureza do nativo; o conceito de verdade objetiva (como os de representação e de natureza) é parte das regras desse jogo, não do que se propõe aqui. De resto, uma vez dados os objetos que o jogo clássico se dá, seus resultados são freqüentemente convincentes, ou pelo menos, como gostam de dizer os adeptos desse jogo, 'plausíveis' 6 . Recusar esse jogo significa apenas dar-se outros objetos, compatíveis com as outras regras acima esboçadas.

O que estou sugerindo, em poucas palavras, é a incompatibilidade entre duas concepções da antropologia, e a necessidade de escolher entre elas. De um lado, temos uma imagem do conhecimento antropológico como resultando da aplicação de conceitos extrínsecos ao objeto: sabemos de antemão o que são as relações sociais, ou a cognição, o parentesco, a religião, a política etc., e vamos ver como tais entidades se realizam neste ou naquele contexto etnográfico - como elas se realizam, é claro, pelas costas dos interessados. De outro (e este é o jogo aqui proposto), está uma idéia do conhecimento antropológico como envolvendo a pressuposição fundamental de que os procedimentos que caracterizam a 
investigação são conceitualmente da mesma ordem que os procedimentos investigados ${ }^{7}$. Tal equivalência no plano dos procedimentos, sublinhe-se, supõe e produz uma não-equivalência radical de tudo o mais. Pois, se a primeira concepção de antropologia imagina cada cultura ou sociedade como encarnando uma solução específica de um problema genérico - ou como preenchendo uma forma universal (o conceito antropológico) com um conteúdo particular - , a segunda, ao contrário, suspeita que os problemas eles mesmos são radicalmente diversos; sobretudo, ela parte do princípio de que o antropólogo não sabe de antemão quais são eles. $O$ que a antropologia, nesse caso, põe em relação são problemas diferentes, não um problema único ('natural') e suas diferentes soluções ('culturais'). A “arte da antropologia" (Gell 1999), penso eu, é a arte de determinar os problemas postos por cada cultura, não a de achar soluções para os problemas postos pela nossa. E é exatamente por isso que o postulado da continuidade dos procedimentos é um imperativo epistemológico8.

Dos procedimentos, repito, não dos que os levam a cabo. Pois tampouco se trata de condenar o jogo clássico por produzir resultados subjetivamente falseados, ao não reconhecer ao nativo sua condição de Sujeito: ao mirá-lo com um olhar distanciado e carente de empatia, construí-lo como um objeto exótico, diminuí-lo como um primitivo não coevo ao observador, negar-lhe o direito humano à interlocução - conhece-se a litania. Não é nada disso. Antes pelo contrário, penso. É justo porque o antropólogo toma o nativo muito facilmente por um outro sujeito que ele não consegue vê-lo como um sujeito outro, como uma figura de Outrem que, antes de ser sujeito ou objeto, é a expressão de um mundo possível. É por não aceitar a condição de 'não-sujeito' (no sentido de outro que o sujeito) do nativo que o antropólogo introduz, sob a capa de uma proclamada igualdade de fato com este, sua sorrateira vantagem de direito. Ele sabe demais sobre o nativo desde antes do início da partida; ele predefine e circunscreve os mundos possíveis expressos por esse outrem; a alteridade de outrem foi radicalmente separada de sua capacidade de alteração. O autêntico animista é o antropólogo, e a observação participante é a verdadeira (ou seja, falsa) participação primitiva.

Não se trata, portanto, de propugnar uma forma de idealismo intersubjetivo, nem de fazer valer os direitos da razão comunicacional ou do consenso dialógico. M eu ponto de apoio aqui é o conceito acima evocado, o de Outrem como estrutura a priori. Ele está proposto no conhecido comentário de Gilles Deleuze ao Vendredi de Michel Tournier ${ }^{9}$. Lendo o livro de Tournier como a 
descrição ficcional de uma experiência metafísica - o que é um mundo sem outrem? - , Deleuze procede a uma indução dos efeitos da presença desse outrem a partir dos efeitos causados por sua ausência. Outrem aparece, assim, como a condição do campo perceptivo: o mundo fora do alcance da percepção atual tem sua possibilidade de existência garantida pela presença virtual de um outrem por quem ele é percebido; o invisível para mim subsiste como real por sua visibilidade para outrem ${ }^{10}$. A ausência de outrem acarreta a desaparição da categoria do possível; caindo esta, desmorona o mundo, que se vê reduzido à pura superfície do imediato, e o sujeito se dissolve, passando a coincidir com as coisas-em-si (ao mesmo tempo em que estas se desdobram em duplos fantasmáticos). Outrem, porém, não é ninguém, nem sujeito nem objeto, mas uma estrutura ou relação, a relação absoluta que determina a ocupação das posições relativas de sujeito e de objeto por personagens concretos, bem como sua alternância: outrem designa a mim para o outro Eu e o outro eu para mim. Outrem não é um elemento do campo perceptivo; é o princípio que o constitui, a ele e a seus conteúdos. Outrem não é, portanto, um ponto de vista particular, relativo ao sujeito (o 'ponto de vista do outro' em relação ao meu ponto de vista ou vice-versa), mas a possibilidade de que haja ponto de vista - ou seja, é o conceito de ponto de vista. Ele é o ponto de vista que permite que o Eu e o O utro acedam a um ponto de vista11.

Deleuze prolonga aqui criticamente a famosa análise de Sartre sobre o 'olhar', afirmando a existência de uma estrutura anterior à reciprocidade de perspectivas do regard sartriano. O que é essa estrutura? Ela é a estrutura do possível: Outrem é a expressão de um mundo possível. Um possível que existe realmente, mas que não existe atualmente fora de sua expressão em outrem. O possível exprimido está envolvido ou implicado no exprimente (que Ihe permanece entretanto heterogêneo), e se acha efetuado na linguagem ou no signo, que é a realidade do possível enquanto tal - o sentido. $O$ Eu surge então como explicação desse implicado, atualização desse possível, ao tomar o lugar que Ihe cabe (o de 'eu') no jogo de linguagem. O sujeito é assim efeito, não causa; ele é o resultado da interiorização de uma relação que Ihe é exterior — ou antes, de uma relação à qual ele é interior: as relações são originariamente exteriores aos termos, porque os termos são interiores às relações. “Há vários sujeitos porque há outrem, e não o contrário" (Deleuze e Guattari 1991:22).

O problema não está, portanto, em ver o nativo como objeto, e a solução não reside em pô-lo como sujeito. Que o nativo seja um sujeito, não há a menor dúvida; maso que pode ser um sujeito, eis precisamente o 
que o nativo obriga o antropólogo a pôr em dúvida. Tal é a 'cogitação' especificamente antropológica; só ela permite à antropologia assumir a presença virtual de Outrem que é sua condição - a condição de passagem de um mundo possível a outro -, e que determina as posições derivadas e vicárias de sujeito e de objeto.

O físico interroga o neutrino, e não pode discordar dele; o antropólogo responde pelo nativo, que então só pode (de direito e, freqüentemente, de fato) concordar com ele. O físico precisa se associar ao neutrino, pensar com seu recalcitrante objeto; o antropólogo associa o nativo a si mesmo, pensando que seu objeto faz as mesmas associações que ele isto é, que o nativo pensa como ele. O problema é que o nativo certamente pensa, como o antropólogo; mas, muito provavelmente, ele não pensa como o antropólogo. O nativo é, sem dúvida, um objeto especial, um objeto pensante ou um sujeito. Mas se ele é objetivamente um sujeito, então o que ele pensa é um pensamento objetivo, a expressão de um mundo possível, ao mesmo título que o que pensa o antropólogo. Por isso, a diferença malinowskiana entre o que o nativo pensa (ou faz) e o que ele pensa que pensa (ou que faz) é uma diferença espúria. É justamente por ali, por essa bifurcação da natureza do outro, que pretende entrar o antropólogo (que faria o que pensa) ${ }^{12}$. A boa diferença, ou diferença real, é entre o que pensa (ou faz) o nativo e o que o antropólogo pensa que (e faz com o que) o nativo pensa, e são esses dois pensamentos (ou fazeres) que se confrontam. Tal confronto não precisa se resumir a uma mesma equivocidade de parte a parte - o equívoco nunca é o mesmo, as partes não o sendo; e de resto, quem definiria a adequada univocidade? - , mas tampouco precisa se contentar em ser um diálogo edificante. O confronto deve poder produzir a mútua implicação, a comum alteração dos discursos em jogo, pois não se trata de chegar ao consenso, mas ao conceito.

Evoquei a distinção criticista entre o quid facti e o quid juris. Ela me pareceu útil porque o primeiro problema a resolver consiste nessa avaliação da pretensão ao conhecimento implícita no discurso do antropólogo. Tal problema não é cognitivo, ou seja, psicológico; não concerne à possibilidade empírica do conhecimento de uma outra cultura13. Ele é epistemológico, isto é, político. Ele diz respeito à questão propriamente transcendental da legitimidade atribuída aos discursos que entram em relação de conhecimento, e, em particular, às relações de ordem que se decide estatuir entre esses discursos, que certamente não são inatas, como tampouco o são seus pólos de enunciação. Ninguém nasce antropólogo, e menos ainda, por curioso que pareça, nativo. 


\section{No limite}

Nos últimos tempos, os antropólogos temos mostrado grande inquietação a respeito da identidade e destino de nossa disciplina: o que ela é, se ela ainda é, o que ela deve ser, se ela tem o direito de ser, qual é seu objeto próprio, seu método, sua missão, e por aí afora (ver, por exemplo, M oore 1999). Fiquemos com a questão do objeto, que implica as demais. Seria ele a cultura, como na tradição disciplinar americana? A organização social, como na tradição britânica? A natureza humana, como na tradição francesa? Penso que a resposta adequada é: todas as respostas anteriores, e nenhuma delas. Cultura, sociedade e natureza dão na mesma; tais noções não designam o objeto da antropologia, seu assunto, mas sim seu problema, aquilo que ela justamente não pode assumir (Latour 1991:109110, 130), porquanto há uma 'tradição' a mais a levar em conta, aquela que conta mais: a tradição do nativo.

A dmitamos, pois se há de começar por algum lugar, que a matéria privilegiada da antropologia seja a socialidade humana, isto é, o que vamos chamando de 'relações sociais'; e aceitemos a ponderação de que a 'cultura', por exemplo, não tem existência independente de sua atualização nessas relações ${ }^{14}$. Resta, ponto importante, que tais relações variam no espaço e no tempo; e se a cultura não existe fora de sua expressão relacional, então a variação relacional também é variação cultural, ou, dito de outro modo, 'cultura' é o nome que a antropologia dá à variação relacional.

M as essa variação relacional - não obrigaria ela a supormos um sujeito, um substrato invariante do qual ela se predica? Questão sempre latente, e insistente em sua suposta evidência; questão, sobretudo, mal formulada. Pois o que varia crucialmente não é o conteúdo das relações, mas sua idéia mesma: o que conta como relação nesta ou naquela cultura. Não são as relações que variam, são as variações que relacionam. E se assim é, então o substrato imaginado das variações, a 'natureza humana' - para passarmos ao conceito caro à terceira grande tradição antropológica -, mudaria completamente de função, ou melhor, deixaria de ser uma substância e se tornaria uma verdadeira função. A natureza deixaria de ser uma espécie de máximo denominador comum das culturas (máximo que é um mínimo, uma humanitas minima), uma sorte de fundo de semelhança obtido por cancelamento das diferenças a fim de constituir um sujeito constante, um emissor-referente estável dos significados culturais variáveis (como se as diferenças não fossem igualmente naturais!). Ela passaria a ser al go como um mínimo múltiplo comum das 
diferenças - maior que as culturas, não menor que elas -, ou algo como a integral parcial das diferentes configurações relacionais que chamamos 'culturas'15. O 'mínimo' é, nesse caso, a multiplicidade comum ao humano - humanitas multiplex. A dita natureza deixaria assim de ser uma substância auto-semelhante situada em algum lugar natural privilegiado (o cérebro, por exemplo), e assumiria ela própria o estatuto de uma relação diferencial, disposta entre os termos que ela 'naturaliza': tornar-se-ia o conjunto de transformações requeridas para se descrever as variações entre as diferentes configurações relacionais conhecidas. Ou, para usarmos ainda uma outra imagem, ela se tornaria aqui um puro limite - mas não no sentido geométrico de limitação, isto é, de perímetro ou termo que constrange e define uma forma substancial (recorde-se a idéia, tão presente no vocabulário antropológico, das enceintes mentales), e sim no sentido matemático de ponto para o qual tende uma série ou uma relação: limite-tensão, não limite-contorno ${ }^{16}$. A natureza humana, nesse caso, seria uma operação teórica de 'passagem ao limite', que indica aquilo de que os seres humanos são virtualmente capazes, e não uma limitação que os determina atualmente a não ser outra coisa ${ }^{17}$. Se a cultura é um sistema de diferenças, como gostavam de dizer os estruturalistas, então a natureza também o é: diferenças de diferenças.

O motivo (caracteristicamente kantiano, escusado dizer) do limite-contorno, tão presente no imaginário da disciplina, é particularmente conspícuo quando o horizonte assim delimitado consiste na chamada natureza humana, como é o caso das orientações natural-universalistas tais a sociobiologia ou a psicologia evolucionária, e, em boa medida, o próprio estruturalismo. M as ele está presente também nos discursos sobre as culturas humanas, onde dá testemunho das limitações - se posso me exprimir assim - da postura cultural-relativista clássica. Recorde-se o tema consagrado pela frase de EvansPritchard a respeito da bruxaria zande - "os Azande não podem pensar que seu pensamento está errado"-; ou a imagem antropológica corrente da cultura como prótese ocular (ou crivo classificatório) que só permite 'ver as coisas' de um certo modo (ou que oculta certos pedaços da realidade); ou ainda, para citarmos um exemplo mais recente, a metáfora do "bocal" em que cada época histórica estaria encerrada (Veyne 1983)18. Seja com respeito à natureza, seja às culturas, o motivo me parece igualmente 'limitado'. Se quiséssemos ser perversos, diríamos que sua neutral idade estratégica, sua co-presença nos campos inimigos do universalismo e do relativismo, é uma prova el oqüente de que a noção de enceinte mentale é uma das enceintes mentales características de nosso comum 'bocal' histórico. De qualquer 
modo, ela mostra bem que a suposta oposição entre universalismo naturalista e relativismo culturalista é, no mínimo, muito relativa (e perfeitamente cultural), pois se resume a uma questão de escolher as dimensões do bocal, o tamanho do cárcere em que jazemos prisioneiros: a cela incluiria catolicamente toda a espécie humana, ou seria feita sob medida para cada cultura? Haveria talvez uma só grande penitenciária 'natural', com diferentes alas 'cul turais', umas com celas talvez um pouco mais espaçosas que outras?19

O objeto da antropologia, assim, seria a variação das relações sociais. Não das relações sociais tomadas como uma província ontológica distinta, mas de todos os fenômenos possíveis enquanto relações sociais, enquanto implicam relações sociais: de todas as relações como sociais. M as isso de uma perspectiva que não seja totalmente dominada pela doutrina ocidental das relações sociais; uma perspectiva, portanto, pronta a admitir que o tratamento de todas as relações como sociais pode levar a uma reconceituação radical do que seja 'o social'. Digamos então que a antropologia se distinga dos outros discursos sobre a socialidade humana não por dispor de uma doutrina particularmente sólida sobre a natureza das relações sociais, mas, ao contrário, por ter apenas uma vaga idéia inicial do que seja uma relação. Pois seu problema característico consiste menos em determinar quais são as relações sociais que constituem seu objeto, e muito mais em se perguntar o que seu objeto constitui como relação social, o que é uma relação social nos termos de seu objeto, ou melhor, nos termos formuláveis pela relação (social, naturalmente, e constitutiva) entre o 'antropólogo' e o 'nativo'.

\section{Da concepção ao conceito}

Isso tudo não quereria apenas dizer que o ponto de vista aqui defendido, e exemplificado em meu trabalho sobre o perspectivismo ameríndio (Viveiros de Castro 1996), é ‘o ponto de vista do nativo', como os antropólogos professam de longa data? De fato, não há nada de particularmente original no ponto de vista adotado; a originalidade que conta é a do ponto de vista indígena, não a do meu comentário. Mas, sobre a questão de o objetivo ser o ponto de vista do nativo - a resposta é sim, e não. $\mathrm{Sim}$, e mesmo mais, porque meu problema, no artigo citado, foi o de saber o que é um 'ponto de vista' para o nativo, entenda-se, qual é o conceito de ponto de vista presente nas culturas amazônicas: qual o ponto de vista nativo sobre o ponto de vista. $\mathrm{N}$ ão, por outro lado, porque o conceito 
nativo de ponto de vista não coincide com o conceito de ponto de vista do nativo; e porque meu ponto de vista não pode ser o do nativo, mas o de minha relação com o ponto de vista nativo. O que envolve uma dimensão essencial de ficção, pois se trata de pôr em ressonância interna dois pontos de vista completamente heterogêneos.

$\mathrm{O}$ que fiz em meu artigo sobre o perspectivismo foi uma experiência de pensamento e um exercício de ficção antropológica. A expressão 'experiência de pensamento' não tem aqui o sentido usual de entrada imaginária na experiência pelo (próprio) pensamento, mas o de entrada no (outro) pensamento pela experiência real: não se trata de imaginar uma experiência, mas de experimentar uma imaginação20. A experiência, no caso, é a minha própria, como etnógrafo e como leitor da bibliografia etnológica sobre a Amazônia indígena, e o experimento, uma ficção controlada por essa experiência. Ou seja, a ficção é antropológica, mas sua antropologia não é fictícia.

Em que consiste tal ficção? Ela consiste em tomar as idéias indígenas como conceitos, e em extrair dessa decisão suas conseqüências: determinar o solo pré-conceitual ou o plano de imanência que tais conceitos pressupõem, os personagens conceituais que eles acionam, e a matéria do real que eles põem. Tratar essas idéias como conceitos não signifi$\mathrm{ca}$, note-se bem, que elas sejam objetivamente determinadas como outra coisa, outro tipo de objeto atual. Pois tratá-las como cognições individuais, representações coletivas, atitudes proposicionais, crenças cosmológicas, esquemas inconscientes, disposições encorporadas e por aí afora - estas seriam outras tantas ficções teóricas que apenas escolhi não acolher.

Assim, o tipo de trabalho que advogo aqui não é, nem um estudo de 'mentalidade primitiva' (supondo que tal noção ainda tenha um sentido), nem uma análise dos 'processos cognitivos' indígenas (supondo que estes sejam acessíveis, no presente estado do conhecimento psicológico e etnográfico). M eu objeto é menos o modo de pensar indígena que os objetos desse pensar, o mundo possível que seus conceitos projetam. Não se trata, tampouco, de reduzir a antropologia a uma série de ensaios etnossociológicos sobre visões de mundo. Primeiro, porque não há mundo pronto para ser visto, um mundo antes da visão, ou antes, da divisão entre o visível (ou pensável) e o invisível (ou pressuposto) que institui o horizonte de um pensamento. Segundo, porque tomar as idéias como conceitos é recusar sua explicação em termos da noção transcendente de contexto (ecológico, econômico, político etc.), em favor da noção imanente de problema, de campo problemático onde as idéias estão implicadas. $N$ ão se trata, por fim, de propor uma interpretação do pensamento ameríndio, 
mas de realizar uma experimentação com ele, e portanto com o nosso. No inglês dificilmente traduzível de Roy Wagner: "every understanding of another culture is an experiment with one's own" (1981:12).

Tomar as idéias indígenas como conceitos é afirmar uma intenção antipsicologista, pois o que se visa é uma imagem de jure do pensamento, irredutível à cognição empírica, ou à análise empírica da cognição feita em termos psicológicos. A jurisdição do conceito é extraterritorial às faculdades cognitivas e aos estados internos dos sujeitos: os conceitos são objetos ou eventos intelectuais, não estados ou atributos mentais. Eles certamente 'passam pela cabeça' (ou, como se diria em inglês, 'cruzam a mente'): mas eles não ficam lá, e sobretudo, não estão lá prontos - eles são inventados. Deixemos as coisas claras. Não acho que os índios americanos 'cognizem' diferentemente de nós, isto é, que seus processos ou categorias 'mentais' sejam diferentes dos de quaisquer outros humanos. Não é o caso de imaginar os índios como dotados de uma neurofisiologia peculiar, que processaria diversamente o diverso. No que me concerne, penso que eles pensam exatamente 'como nós'; mas penso também que o que eles pensam, isto é, os conceitos que eles se dão, as 'descrições' que eles produzem, são muito diferentes dos nossos - e portanto que o mundo descrito por esses conceitos é muito diverso do nosso ${ }^{21}$. No que concerne aos índios, penso - se minhas análises do perspectivismo estão corretas - que eles pensam que todos os humanos, e além destes, muitos outros sujeitos não-humanos, pensam exatamente 'como eles', mas que isso, longe de produzir (ou resultar de) uma convergência referencial universal, é exatamente a razão das divergências de perspectiva.

A noção de conceito supõe uma imagem do pensamento como atividade distinta da cognição, e como outra coisa que um sistema de representações. O que me interessa no pensamento nativo americano, assim, não é nem o saber local e suas representações mais ou menos verdadeiras sobre o real - o 'indigenous knowledge' hoje tão disputado no mercado global de representações - , nem a cognição indígena e suas categorias mentais, cuja maior ou menor representatividade, do ponto de vista das faculdades da espécie, as ciências do espírito pretendem explorar. Nem representações, individuais ou coletivas, racionais ou ('aparentemente') irracionais, que exprimiriam parcialmente estados de coisas anteriores e exteriores a elas; nem categorias e processos cognitivos, universais ou particulares, inatos ou adquiridos, que manifestariam propriedades de uma coisa do mundo, seja ela a mente ou a sociedade. M eu objeto são os conceitos indígenas, os mundos que eles constituem (mundos que assim os exprimem), o fundo virtual de onde eles procedem e que 
eles pressupõem. Os conceitos, ou seja, as idéias e os problemas da 'razão' indígena, não suas categorias do 'entendimento'.

Como terá ficado claro, a noção de conceito tem aqui um sentido bem determinado. Tomar as idéias indígenas como conceitos significa tomá-las como dotadas de uma significação propriamente filosófica, ou como potencialmente capazes de um uso filosófico.

Decisão irresponsável, dir-se-á, tanto mais que não são só os índios que não são filósofos, mas, sublinhe-se com força, tampouco o presente autor. Como aplicar, por exemplo, a noção de conceito a um pensamento que, aparentemente, nunca achou necessário se debruçar sobre si mesmo, e que remeteria antes ao esquematismo fluente e variegado do símbolo, da figura e da representação coletiva que à arquitetura rigorosa da razão conceitual? Não existe um bem conhecido abismo histórico e psicológico, uma "ruptura decisiva" entre a imaginação mítica pan-humana e o universo da racionalidade helênico-ocidental (Vernant 1996:229)? Entre a bricolagem do signo e a engenharia do conceito (Lévi-Strauss 1962)? Entre a transcendência paradigmática da Figura e a imanência sintagmática do Conceito (Deleuze e Guattari 1991)? Entre uma economia intelectual de tipo imagístico-mostrativa e outra de tipo doutrinal-demonstrativa (Whitehouse 2000)? Enfim, quanto a tudo isso, que é caudatário mais ou menos direto de Hegel, tenho al gumas dúvidas. E antes disso, tenho meus motivos para falar em conceito. Vou-me ater aqui apenas ao primeiro deles, que decorre da decisão de tomar as idéias nativas como situadas no mesmo plano que as idéias antropológicas.

A experiência proposta aqui, dizia eu acima, começa por afirmar a equivalência de direito entre os discursos do antropólogo e do nativo, bem como a condição mutuamente constituinte desses discursos, que só acedem como tais à existência ao entrarem em relação de conhecimento. Os conceitos antropológicos atualizam tal relação, e são por isso completamente relacionais, tanto em sua expressão como em seu conteúdo. Eles não são, nem reflexos verídicos da cultura do nativo (o sonho positivista), nem projeções ilusórias da cultura do antropólogo (o pesadelo construcionista). O que eles refletem é uma certa relação de inteligibilidade entre as duas culturas, e o que el es projetam são as duas culturas como seus pressupostos imaginados. Eles operam, com isso, um duplo desenraizamento: são como vetores sempre a apontar para o outro lado, interfaces transcontextuais cuja função é representar, no sentido diplomático do termo, o outro no seio do mesmo, lá como cá.

Os conceitos antropológicos, em suma, são relativos porque são relacionais - e são relacionais porque são relatores. Tais origem e função 
costumam vir marcadas na 'assinatura' característica desses conceitos por uma palavra estranha: mana, totem, kula, potlatch, tabu, gumsa/gumlao... Outros conceitos, não menos autênticos, portam uma assinatura etimológica que evoca antes as analogias entre a tradição cultural de onde emergiu a disciplina e as tradições que são seu objeto: dom, sacrifício, parentesco, pessoa... Outros, enfim, igualmente legítimos, são invenções vocabulares que procuram generalizar dispositivos conceituais dos povos estudados - animismo, oposição segmentar, troca restrita, cismogênese... - ou, inversamente, e mais problematicamente, desviam para o interior de uma economia teórica específica certas noções difusas de nossa tradição - proibição do incesto, gênero, símbolo, cultura... -, buscando universalizá-las²2.

Vemos então que numerosos conceitos, problemas, entidades e agentes propostos pelas teorias antropológicas têm sua origem no esforço imaginativo das sociedades mesmas que elas pretendem explicar. Não estaria aí a originalidade da antropologia, nessa sinergia entre as concepções e práticas provenientes dos mundos do ‘sujeito' e do 'objeto'? Reconhecer isso ajudaria, entre outras coisas, a mitigar nosso complexo de inferioridade diante das "ciências naturais". Como observa Latour:

“A descrição do kula equipara-se à descrição dos buracos negros. Os complexos sistemas de aliança são tão imaginativos como os complexos cenários evolutivos propostos para os genes egoístas. Compreender a teologia dos aborígines australianos é tão importante quanto cartografar as grandes falhas submarinas. O sistema de posse da terra nas Trobriand é um objetivo científico tão interessante como a sondagem do gelo das calotas polares. Se a questão é saber o que importa na definição de uma ciência - a capacidade de inovação no que diz respeito às agências que povoam nosso mundo - , então a antropologia estaria bem próxima do topo da hierarquia disciplinar [...]" (1996a:5)23.

A analogia feita nessa passagem é entre as concepções indígenas e os objetos das ciências ditas naturais. Esta é uma perspectiva possível, e mesmo necessária: deve-se poder produzir uma descrição científica das idéias e práticas indígenas, como se fossem objetos do mundo, ou melhor, para que sejam objetos do mundo. (É preciso não esquecer que os objetos científicos de Latour são tudo menos entidades 'objetivas' e indiferentes, pacientemente à espera de uma descrição.) Outra estratégia possível é a de comparar as concepções indígenas às teorias científicas, como o faz Horton, segundo sua "tese da similaridade" (1993:348-354), que antecipa alguns aspectos da antropologia simétrica de Latour. Outra ain- 
da é a estratégia aqui advogada. Cuido que a antropologia sempre andou demasiado obcecada com a 'Ciência', não só em relação a si mesma - se ela é ou não, pode ou não, deve ou não ser uma ciência - , como sobretudo, e este é o real problema, em relação às concepções dos povos que estuda: seja para desqualificá-las como erro, sonho, ilusão, e em seguida explicar cientificamente como e por que os 'outros' não conseguem (se) explicar cientificamente; seja para promovê-las como mais ou menos homogêneas à ciência, frutos de uma mesma vontade de saber consubstancial à humanidade. Assim a similaridade de Horton, assim a ciência do concreto de Lévi-Strauss (Latour 1991:133-134). A imagem da ciência, essa espécie de padrão-ouro do pensamento, não é porém o único terreno, nem necessariamente o melhor, em que podemos nos relacionar com a atividade intelectual dos povos estrangeiros à tradição ocidental.

Imagine-se uma outra analogia que a de Latour, ou uma outra similaridade que a de Horton. Uma analogia onde, em lugar de tomar as concepções indígenas como entidades semelhantes aos buracos negros ou às falhas tectônicas, tomemo-las como algo de mesma ordem que o cogito ou a mônada. Diríamos então, parafraseando a citação anterior, que o conceito melanésio da pessoa como "divíduo" (Strathern 1988) é tão imaginativo como o individualismo possessivo de Locke; que compreender a "filosofia da chefia ameríndia" (Clastres 1974) é tão importante quanto comentar a doutrina hegeliana do Estado; que a cosmogonia maori se equipara aos paradoxos el eáticos e às antinomias kantianas (Schrempp 1992); que o perspectivismo amazônico é um objetivo filosófico tão interessante como compreender o sistema de Leibniz... E se a questão é saber o que importa na avaliação de uma filosofia - sua capacidade de criar novos conceitos -, então a antropologia, sem pretender substituir a filosofia, não deixa de ser um poderoso instrumento filosófico, capaz de ampliar um pouco os horizontes tão etnocêntricos de nossa filosofia, e de nos livrar, de passagem, da antropologia dita 'filosófica'. Na definição vigorosa de Tim Ingold (1992:696), que é melhor deixar no original: "anthropology is philosophy with the people in". Por 'people', Ingold entende aqui os "ordinary people", as pessoas comuns (Ingold 1992:696); mas ele está também jogando com o significado de 'people' como 'povo', e mais ainda, como 'povos'. Uma filosofia com outros povos dentro, então: a possibilidade de uma atividade filosófica que mantenha uma relação com a não-filosofia - a vida - de outros povos do planeta, além de com a nossa própria24. Não só as pessoas comuns, então, mas sobretudo os povos incomuns, aqueles que estão fora de nossa esfera de 'comunicação'. Se a filosofia 'real' abunda em selvagens imaginários, a geofilosofia visa- 
da pela antropologia faz uma filosofia 'imaginária' com selvagens reais. Real toads in imaginary gardens, como disse a poeta M arianne M oore.

Note-se, na paráfrase que fizemos mais acima, o deslocamento que importa. Agora não se trataria mais, ou apenas, da descrição antropológica do kula (enquanto forma melanésia de socialidade), mas do kula enquanto descrição melanésia (da 'socialidade' como forma antropológica); ou ainda, seria preciso continuar a compreender a "teologia australiana", mas agora como constituindo ela própria um dispositivo de compreensão; do mesmo modo, os complexos sistemas de aliança ou de posse da terra deveriam ser vistos como imaginações sociológicas indígenas. É claro que será sempre necessário descrever o kula como uma descrição, compreender a religião aborígine como um compreender, e imaginar a imaginação indígena: é preciso saber transformar as concepções em conceitos, extraí-los delas e devolvê-los a elas. E um conceito é uma relação complexa entre concepções, um agenciamento de intuições préconceituais; no caso da antropologia, as concepções em relação incluem, antes de mais nada, as do antropólogo e as do nativo - relação de relações. Os conceitos nativos são os conceitos do antropólogo. Por hipótese.

\section{Não explicar, nem interpretar: multiplicar, e experimentar}

Roy Wagner, desde seu The Invention of Culture, foi um dos primeiros antropólogos que soube radicalizar a constatação de uma equivalência entre o antropólogo e o nativo decorrente de sua comum condição cultural. Do fato de que a aproximação a uma outra cultura só pode se fazer nos termos daquela do antropólogo, Wagner conclui que o conhecimento antropológico se define por sua "objetividade relativa” (1981:2). Isto não significa uma objetividade deficiente, isto é, subjetiva ou parcial, mas uma objetividade intrinsecamente relacional, como se depreende do que se segue:

“A idéia de cultura [...] coloca o pesquisador em posição de igualdade com
aquele que ele pesquisa: ambos 'pertencem a uma cultura'. Como cada cul-
tura pode ser vista como uma manifestação específica [...] do fenômeno
humano, e como jamais se descobriu um método infalível de 'graduar' dife-
rentes culturas e arranjá-las em tipos naturais, assumimos que cada cultura,
como tal, é equivalente a qualquer outra. Tal postulado chama-se 'relativi-
dade cultural'. [...] A combinação dessas duas implicações da idéia de cultu-
ra, isto é, o fato de que os antropólogos pertencemos a uma cultura (objetivi-
dade relativa) e que somos obrigados a postular que todas as culturas se 
equivalem (relatividade cultural), leva-nos a uma proposição geral a respeito do estudo da cultura. Como atesta a repetição da idéia de 'relativo', a apreensão de outra cultura envolve o relacionamento [relationship] entre duas variedades do fenômeno humano; ela visa a criação de uma relação intelectual entre elas, uma compreensão que inclua a ambas. A idéia de 'relacionamento' é importante aqui porque é mais apropriada a essa aproximação de duas entidades (ou pontos de vista) equivalentes que noções como 'análise' ou 'exame', que traem uma pretensão a uma objetividade absoluta” (Wagner 1981:2-3).

Ou, como diria Deleuze: não se trata de afirmar a relatividade do verdadeiro, mas sim a verdade do relativo. É digno de nota que Wagner associe a noção de relação à de ponto de vista (os termos relacionados são pontos de vista), e que essa idéia de uma verdade do relativo defina justamente o que Deleuze chama de "perspectivismo". Pois o perspectivismo - o de Leibniz e Nietzsche como o dos Tukano ou J uruna - não é um relativismo, isto é, afirmação de uma relatividade do verdadeiro, mas um relacionalismo, pelo qual se afirma que a verdade do relativo é a relação.

Indaguei o que aconteceria se recusássemos a vantagem epistemológica do discurso do antropólogo sobre o do nativo; se entendêssemos a relação de conhecimento como suscitando uma modificação, necessariamente recíproca, nos termos por ela relacionados, isto é, atualizados. Isso é o mesmo que perguntar: o que acontece quando se leva o pensamento nativo a sério? Quando o propósito do antropólogo deixa de ser o de explicar, interpretar, contextualizar, racionalizar esse pensamento, e passa a ser o de o utilizar, tirar suas conseqüências, verificar os efeitos que ele pode produzir no nosso? O que é pensar o pensamento nativo? Pensar, digo, sem pensar se aquilo que pensamos (o outro pensamento) é "aparentemente irracional" 25 , ou pior ainda, naturalmente racional 26 , mas pensá-lo como algo que não se pensa nos termos dessa alternativa, algo inteiramente alheio a esse jogo?

Levar a sério é, para começar, não neutralizar. É, por exemplo, pôr entre parênteses a questão de saber se e como tal pensamento ilustra universais cognitivos da espécie humana, explica-se por certos modos de transmissão social do conhecimento, exprime uma visão de mundo culturalmente particular, valida funcionalmente a distribuição do poder político, e outras tantas formas de neutralização do pensamento alheio. Suspender tal questão ou, pelo menos, evitar encerrar a antropologia nela; decidir, por exemplo, pensar o outro pensamento apenas (digamos assim) como uma atualização de virtualidades insuspeitas do pensar. 
Levar a sério significaria, então, 'acreditar' no que dizem os índios, tomar seu pensamento como exprimindo uma verdade sobre o mundo? De forma alguma; esta é outra questão mal colocada. Para crer ou não crer em um pensamento, é preciso primeiro imaginá-lo como um sistema de crenças. $M$ as os problemas autenticamente antropológicos não se põem jamais nos termos psicologistas da crença, nem nos termos logicistas do valor de verdade, pois não se trata de tomar o pensamento al heio como uma opinião, único objeto possível de crença ou descrença, ou como um conjunto de proposições, únicos objetos possíveis dos juízos de verdade. Sabe-se o estrago causado pela antropologia ao definir a relação dos nativos com seu discurso em termos de crença - a cultura vira uma espécie de teologia dogmática (Viveiros de Castro 1993) —, ou ao tratar esse discurso como uma opinião ou como um conjunto de proposições a cultura vira uma teratologia epistêmica: erro, ilusão, loucura, ideologia... 27. Como observa Latour (1996b:15), “a crença não é um estado mental, mas um efeito da relação entre os povos" - e o tipo mesmo do efeito que não pretendo produzir.

O animismo, por exemplo, sobre o qual já escrevi antes (Viveiros de Castro 1996). O Vocabulário de Lalande, que não se mostra, quanto a isso, muito destoante em face de estudos psico-antropológicos recentes sobre o tópico, define "animismo" nestes exatos termos: como um "estado mental". M as o animismo ameríndio pode ser tudo, menos isso. Ele é uma imagem do pensamento, que reparte o fato e o direito, o que cabe de direito ao pensamento e o que remete contingentemente aos estados de coisas; é, mais especificamente, uma convenção de interpretação (Strathern 1999a:239) que pressupõe a personitude formal do que há a conhecer, fazendo assim do pensamento uma atividade e um efeito da relação ('social') entre o pensador e o pensado. Seria apropriado dizer que, por exemplo, o positivismo ou o jusnaturalismo são estados mentais? O mesmo (não) se diga do animismo amazônico: ele não é um estado mental dos sujeitos individuais, mas um dispositivo intelectual transindividual, que toma, aliás, os 'estados mentais' dos seres do mundo como um de seus objetos. Ele não é uma condição da mente do nativo, mas uma 'teoria da mente' aplicada pelo nativo, um modo de resolver, aliás - ou melhor, de dissolver - , o problema eminentemente filosófico das 'outras mentes'.

Se não se trata de descrever o pensamento indígena americano em termos de crença, tampouco então é o caso de relacionar-se a ele sob o modo da crença - seja sugerindo com benevolência seu 'fundo de verdade' alegórico (uma alegoria social, como para os durkheimianos, ou natural, como para os materialistas culturais), seja, pior ainda, imaginan- 
do que ele daria acesso à essência íntima e última das coisas, detentor que seria de uma ciência esotérica infusa. “Uma antropologia que [...] reduz o sentido [meaning] à crença, ao dogma e à certeza cai forçosamente na armadilha de ter de acreditar ou nos sentidos nativos, ou em nossos próprios" (Wagner 1981:30). M as o plano do sentido não é povoado por crenças psicológicas ou proposições lógicas, e o 'fundo' contém outra coisa que verdades. Nem uma forma da doxa, nem uma figura da lógica - nem opinião, nem proposição - , o pensamento nativo é aqui tomado como atividade de simbolização ou prática de sentido: como dispositivo auto-referencial ou tautegórico de produção de conceitos, isto é, de "símbolos que representam a si mesmos" (Wagner 1986).

Recusar-se a pôr a questão em termos de crença parece-me um traço crucial da decisão antropológica. Para marcá-lo, reevoquemos o Outrem deleuziano. Outrem é a expressão de um mundo possível; mas este mundo deve sempre, no curso usual das interações sociais, ser atualizado por um Eu: a implicação do possível em outrem é explicada por mim. Isto significa que o possível passa por um processo de verificação que dissipa entropicamente sua estrutura. Quando desenvolvo o mundo exprimido por outrem, é para validá-lo como real e ingressar nele, ou então para desmenti-lo como irreal: a 'explicação' introduz, assim, o elemento da crença. Descrevendo tal processo, Deleuze indicava a condição-limite que Ihe permitiu a determinação do conceito de Outrem:

“ [E]ssas relações de desenvolvimento, que formam tanto nossas comunidades como nossas contestações com outrem, dissolvem sua estrutura, e a reduzem, em um caso, ao estado de objeto, e, no outro, ao estado de sujeito. Eis por que, para apreender outrem como tal, sentimo-nos no direito de exigir condições especiais de experiência, por mais artificiais que fossem elas: o momento em que o exprimi do ainda não possui (para nós) existência fora do que o exprime - Outrem como expressão de um mundo possível" (1969a:335).

E concluía recordando uma máxima fundamental de sua reflexão: “A regra que invocávamos anteriormente: não se explicar demais, significava, antes de tudo, não se explicar demais com outrem, não explicar outrem demais, manter seus valores implícitos, multiplicar nosso mundo povoando-o de todos esses exprimidos que não existem fora de suas expressões" (Deleuze 1969a:335).

A lição pode ser aproveitada pela antropologia. M anter os valores de outrem implícitos não significa celebrar algum mistério numinoso que eles encerrem; significa a recusa de atualizar os possíveis expressos pelo 
pensamento indígena, a deliberação de guardá-los indefinidamente como possíveis - nem desrealizando-os como fantasias dos outros, nem fantasiando-os como atuais para nós. A experiência antropológica, nesse caso, depende da interiorização formal das "condições especiais e artificiais" de que fala Deleuze: o momento em que o mundo de outrem não existe fora de sua expressão transforma-se em uma condição eterna, isto é, interna à relação antropológica, que realiza esse possível como virtual28. Se há algo que cabe de direito à antropologia, não é certamente a tarefa de explicar o mundo de outrem, mas a de multiplicar nosso mundo, "povoando-o de todos esses exprimidos que não existem fora de suas expressões".

\section{De porcos e corpos}

Realizar os possíveis nativos como virtualidades é o mesmo que tratar as idéias nativas como conceitos. Dois exemplos.

1. Os porcos dos índios. É comum encontrar-se na etnografia americana a idéia de que, para os índios, os animais são humanos. Tal formulação condensa uma nebulosa de concepções sutilmente variadas, que não cabe aqui elaborar: não são todos os animais que são humanos, e não são só el es que o são; os animais não são humanos o tempo todo; eles foram humanos mas não o são mais; eles tornam-se humanos quando se acham fora de nossas vistas; eles apenas pensam que são humanos; eles vêem-se como humanos; el es têm uma alma humana sob um corpo animal; eles são gente assim como os humanos, mas não são humanos exatamente como a gente; e assim por diante. Além disso, 'animal' e 'humano' são traduções equívocas de certas palavras indígenas - e não esqueçamos que estamos diante de centenas de línguas distintas, na maioria das quais, aliás, a cópula não costuma vir marcada por um verbo. M as não importa, no momento. Suponhamos que enunciados como "os animais são humanos" ou "certos animais são gente" façam algum sentido, e um sentido que nada tenha de 'metafórico', para um dado grupo indígena. Tanto sentido, digamos (mas não exatamente o mesmo tipo de sentido), quanto o que a afirmação aparentemente inversa, e hoje tão pouco escandalosa - "os humanos são animais" - , faz para nós. Suponhamos, então, que o primeiro enunciado faça sentido para, por exemplo, os Ese Eja da A mazônia boliviana: "A afirmação, que eu freqüentemente ouvi, de que 'todos os animais são Ese Eja' [...]" (Alexiades 1999:179)29.

Pois bem. Isabella Lepri, estudante de antropologia que hoje trabaIha, por coincidência, junto a esses mesmos Ese Eja, perguntou-me, pen- 
so que em maio de 1998, se eu acreditava que os pecaris são humanos, como dizem os índios. Respondi que não - e o fiz porque suspeitei (sem nenhuma razão) que ela acreditava que, se os índios diziam tal coisa, então devia ser verdade. Acrescentei, perversa e algo mentirosamente, que só 'acreditava' em átomos e genes, na teoria da relatividade e na evolução das espécies, na luta de classes e na lógica do capital, enfim, nesse tipo de coisa; mas que, como antropólogo, tomava perfeitamente a sério a idéia de que os pecaris são humanos. Ela me contestou: "Como você pode sustentar que leva o que os índios dizem a sério? Isso não é só um modo de ser polido com seus informantes? Como você pode levá-los a sério se só finge acreditar no que eles dizem?"

Essa intimação de hipocrisia me obrigou, é claro, a refletir. Estou convencido de que a questão de Isabella é absolutamente crucial, de que toda antropologia digna desse nome precisa respondê-la, e de que não é nada fácil respondê-la bem.

Uma resposta possível, naturalmente, é aquela contida em uma réplica cortante de Lévi-Strauss ao hermeneutismo mí(s)tico de Ricœur: “É preciso escolher o lado em que se está. Os mitos não dizem nada capaz de nos instruir sobre a ordem do mundo, a natureza do real, a origem do homem ou o seu destino" (1971:571). Em troca, prossegue o autor, os mitos nos ensinam muito sobre as sociedades de onde provêm, e, sobretudo, sobre certos modos fundamentais (e universais) de operação do espírito humano (Lévi-Strauss 1971:571). Opõe-se, assim, à vacuidade referencial do mito, sua plenitude diagnóstica: dizer que os pecaris são humanos não nos 'diz' nada sobre os pecaris, mas muito sobre os humanos que o dizem.

A solução nada tem de especificamente lévi-straussiana; ela é a postura canônica da antropologia, de Durkheim ou dos intelectualistas vitorianos aos dias de hoje. M uito da antropologia chamada cognitiva, por exemplo, pode ser vista como uma elaboração sistemática de tal atitude, que consiste em reduzir o discurso indígena a um conjunto de proposições, selecionar aquelas que são falsas (alternativamente, 'vazias') e produzir uma explicação de por que os humanos acreditam nelas, visto que são falsas ou vazias. Uma explicação, também por exemplo, pode ser aquela que conclui que tais proposições são objeto de um embutimento ou aspeamento por parte de seus enunciadores (Sperber 1974; 1982); elas remetem, portanto, não ao mundo, mas à relação dos enunciadores com seu próprio discurso. Tal relação é igualmente o tema privilegiado das antropologias ditas 'simbolistas', de tipo semântico ou pragmático: enunciados como esse sobre os pecaris falam (ou fazem), 'na verdade', algo 
sobre a sociedade, não sobre o que falam. Eles não ensinariam nada sobre a ordem do mundo e a natureza do real, portanto, nem para nós, nem para os índios. Levar a sério uma afirmação como "os pecaris são humanos", nesse caso, consistiria em mostrar como certos humanos podem levá-la a sério, e mesmo acreditar nela, sem que se mostrem, com isso, irracionais - e, naturalmente, sem que os pecaris se mostrem, por isso, humanos. Salva-se o mundo: salvam-se os pecaris, salvam-se os nativos, e salva-se, sobretudo, o antropólogo.

Essa solução não me satisfaz. Ao contrário, ela me incomoda profundamente. Ela parece implicar que, para levar os índios a sério, quando afirmam coisas como "os pecaris são humanos", é preciso não acreditar no que eles dizem, visto que, se o fizéssemos, não estaríamos nos levando a sério. É preciso achar outra saída. Como não tenho espaço nem, sobretudo e evidentemente, competência para repassar a vasta literatura filosófica sobre a gramática da crença, a certeza, as atitudes proposicionais etc., apresento aqui apenas certas considerações suscitadas, intuitiva mais que reflexivamente, por minha experiência de etnógrafo.

Sou antropólogo, não suinólogo. Os pecaris (ou, como disse um outro antropólogo a propósito dos Nuer, as vacas) não me interessam enormemente, os humanos sim. M as os pecaris interessam enormemente àqueles humanos que dizem que eles são humanos. Portanto, a idéia de que os pecaris são humanos me interessa, a mim também, porque 'diz' algo sobre os humanos que dizem isso. $M$ as não porque ela diga algo que esses humanos não são capazes de dizer sozinhos, e sim porque, nela, esses humanos estão dizendo algo não só sobre os pecaris, mas também sobre o que é ser 'humano'. (Por que os N uer, ao contrário e por exemplo, não dizem que o gado é humano?) $O$ enunciado sobre a humanidade dos pecaris, se certamente revela - ao antropólogo - algo sobre o espírito humano, faz mais que isso - para os índios: ele afirma algo sobre o conceito de humano. Ele afirma, inter alia, que a noção de 'espírito humano', e o conceito indígena de socialidade, incluem em sua extensão os pecaris - e isso modifica radicalmente a intensão desses conceitos relativamente aos nossos.

A crença do nativo ou a descrença do antropólogo não têm nada a fazer aqui. Perguntar(-se) se o antropólogo deve acreditar no nativo é um category mistake equivalente a indagar se o número dois é alto ou verde. Eis os primeiros elementos de minha resposta a Isabella. Quando um antropólogo ouve de um interlocutor indígena (ou lê na etnografia de um colega) algo como "os pecaris são humanos", a afirmação, sem dúvida, interessa-Ihe porque ele ‘sabe' que os pecaris não são humanos. M as esse 
saber - um saber essencialmente arbitrário, para não dizermos burro deve parar aí: seu único interesse consiste em ter despertado o interesse do antropólogo. Não se deve pedir mais a ele. Não se pode, acima de tudo, incorporá-lo implicitamente na economia do comentário antropológico, como se fosse necessário explicar (como se o essencial fosse explicar) por que os índios crêem que os pecaris são humanos quando de fato eles não o são. É inútil perguntar-se se os índios têm ou não razão a esse respeito: pois já não o 'sabemos'? M as o que é preciso saber é justamente o que não se sabe - a saber, o que os índios estão dizendo, quando dizem que os pecaris são humanos.

Uma idéia como esta está longe de ser evidente. O problema que ela coloca não reside na cópula da proposição, como se 'pecari' e 'humano' fossem noções comuns partilhadas pelo antropólogo e pelo nativo, e a única diferença residisse na equação bizarra entre os dois termos. É perfeitamente possível, diga-se de passagem, que o significado lexical ou a interpretação semântica de 'pecari' e 'humano' sejam mais ou menos os mesmos para os dois interlocutores; não se trata de um problema de tradução, ou de decidir se os índios e nós temos os mesmos natural kinds (talvez, talvez). O problema é que a idéia de que os pecaris são humanos é parte do sentido dos 'conceitos' de pecari e de humano naquela cultura, ou melhor, é essa idéia que é o verdadeiro conceito em potência - o conceito que determina o modo como as idéias de pecari e de humano se relacionam. Pois não há 'primeiro' os pecaris e os humanos, cada qual de seu lado, e 'depois' sobrevém a idéia de que os pecaris são humanos: ao contrário, os pecaris, os humanos e sua relação são dados simultaneamente30.

A estreiteza intelectual que ronda a antropologia, em casos como esse, consiste na redução das noções de pecari e de humano exclusivamente a variáveis independentes de uma proposição, quando elas devem ser vistas - se queremos levar os índios a sério - como variações inseparáveis de um conceito. Dizer que os pecaris são humanos, como já observei, não é dizer algo apenas sobre os pecaris, como se 'humano' fosse um predicado passivo e pacífico (por exemplo, o gênero em que se inclui a espécie pecari); tampouco é dar uma simples definição verbal de 'pecari', do tipo “'surubim' é (o nome de) um peixe”. Dizer que os pecaris são humanos é dizer algo sobre os pecaris e sobre os humanos, é dizer algo sobre o que pode ser o humano: se os pecaris têm a humanidade em potência, então os humanos teriam, talvez, uma potência-pecari? Com efeito, se os pecaris podem ser concebidos como humanos, então deve ser possível conceber os humanos como pecaris: o que é ser humano, quando se é 'pecari', e o que é ser pecari, quando se é 'humano'? Quais as 
conseqüências disto? Que conceito se pode extrair de um enunciado como "os pecaris são humanos"? Como transformar a concepção expressa por uma proposição desse tipo em um conceito? Esta é a verdadeira questão.

A ssim, quando seus interlocutores indígenas Ihe dizem (sob condições, como sempre, que cabe especificar) que os pecaris são humanos, o que o antropól ogo deve se perguntar não é se 'acredita ou não' que os pecaris sejam humanos, mas o que uma idéia como essa Ihe ensina sobre as noções indígenas de humanidade e de 'pecaritude'. O que uma idéia como essa, note-se, ensina-Ihe sobre essas noções e sobre outras coisas: sobre as relações entre ele e seu interlocutor, as situações em que tal enunciado é produzido 'espontaneamente', os gêneros de fala e o jogo de linguagem em que ele cabe etc. Essas outras coisas, porém - e gostaria de insistir sobre o ponto - estão muito longe de esgotar o sentido do enunciado. Reduzi-lo a um discurso que 'fala' apenas de seu enunciador é negar a este sua intencionalidade, e, de quebra, é obrigá-lo a trocar seu pecari por nosso humano. O que é um péssimo negócio para o caçador do pecari.

E nesses termos, é óbvio que o etnógrafo tem de acreditar (no sentido de confiar) em seu interlocutor: pois se este não está a Ihe dar uma opinião, mas a ensinar-Ihe o que são os pecaris e os humanos, a explicar como o humano está implicado no pecari... A pergunta, mais uma vez, deve ser: para que serve essa idéia? Em que agenciamentos ela pode entrar? Quais suas conseqüências? Por exemplo: o que se come, quando se come um pecari, se os pecaris são humanos?

E mais: carece ver se o conceito construível a partir de enunciados como esse se exprime de modo realmente adequado pela forma " $X$ é $Y$ ". Pois não se trata tanto de um problema de predicação ou atribuição, mas de definir um conjunto virtual de eventos e de séries em que entram os porcos selvagens de nosso exemplo: os pecaris andam em bando... têm um chefe... são barulhentos e agressivos... sua aparição é súbita e imprevisível... são maus cunhados... comem açaí... vivem sob a terra... são encarnações dos mortos... e assim por diante. Não se trata com isso de identificar os atributos dos pecaris a atributos dos humanos, mas de algo muito diferente. Os pecaris são pecaris e humanos, são humanos naquilo que os humanos não são pecaris; os pecaris implicam os humanos, como idéia, em sua distância mesma diante dos humanos. Assim, quando se diz que os pecaris são humanos, não é para identificá-los aos humanos, mas para diferenciá-los de si mesmos - e a nós de nós mesmos.

Disse anteriormente que a idéia de que os pecaris são humanos está longe de ser evidente. Por certo: nenhuma idéia interessante é evidente. 
Esta, em particular, não é não-evidente porque seja falsa ou inverificável (os índios dispõem de vários modos de verificá-la), mas porque diz algo não-evidente sobre o mundo. Os pecaris não são evidentemente humanos, eles o são não-evidentemente. Isto quereria dizer que tal idéia é 'simbólica', no sentido que Sperber deu a este adjetivo? Entendo que não. Sperber concebe os conceitos indígenas como proposições, e pior, como proposições de segunda classe, "representações semiproposicionais" que prolongam o "saber enciclopédico" sob um modo não-referencializável: confusão do autopositivo com o referencialmente vazio, do virtual com o fictício, da imanência com a clausura... M as é possível ver o 'simbolismo' de outro modo que esse de Sperber, que o toma como algo lógica e cronologicamente posterior à enciclopédia ou à semântica, algo que marca os limites do conhecimento verdadeiro ou verificável, o ponto onde ele se transforma em ilusão. Os conceitos indígenas podem ser ditos simbólicos, mas em sentido muito diferente; não são subproposicionais, são superproposicionais, pois supõem as proposições enciclopédicas mas definem sua significação vital, seu sentido ou valor. As proposições enciclopédicas é que são semiconceituais ou subsimbólicas, não o contrário. O simbólico não é o semiverdadeiro, mas o pré-verdadeiro, isto é, o importante ou relevante: ele diz respeito não ao que 'é o caso', mas ao que importa no que é o caso, ao que interessa para a vida no que é o caso. O que vale um pecari? Essa é a questão, literalmente, interessante ${ }^{31}$.

"Profundo: outra palavra para semiproposicional", ironizou, certa vez, Sperber (1982:173). M as então caberia replicar — banal: outra palavra para proposicional. Profundos, com efeito, os conceitos indígenas certamente o são, pois projetam um fundo, um plano de imanência povoado de intensidades, ou, se o leitor prefere a linguagem de Wittgenstein, um Weltbild quadrilhado por "pseudoproposições" de base que ignoram e precedem a partilha entre o verdadeiro e o falso, "tecendo uma rede que, lançada sobre o caos, pode Ihe dar alguma consistência" (Prado J r. 1998:317). Esse fundo é a "base sem fundamento" que não é nem racional/razoável nem irracional/insensata, mas que "simplesmente está lá como nossa vida" (Prado J r. 1998:319).

2. Os corpos dos índios. M eu colega Peter Gow narrou-me, certa feita, a seguinte cena, presenciada em uma de suas estadas entre os Piro da Amazônia peruana:

Uma professora da missão [na aldeia de] Santa Clara estava tentando convencer uma mulher piro a preparar a comida de seu filho pequeno com água fervida. A mulher replicou: "Se bebemos água fervida, contraímos diarréia". A professora, rindo com zombaria da resposta, expli- 
cou que a diarréia infantil comum é causada justamente pela ingestão de água não-fervida. Sem se abalar, a mulher piro respondeu: “Talvez para o povo de Lima isso seja verdade. Mas para nós, gente nativa daqui, a água fervida dá diarréia. Nossos corpos são diferentes dos corpos de vocês" (Gow, comunicação pessoal, 12/10/00).

O que pode o antropólogo fazer com essa resposta da mulher índia? Várias coisas. Gow, por exemplo, teceu comentários argutos sobre a anedota, em um artigo em preparação:

\begin{abstract}
"Este enunciado simples ["nossos corpos são diferentes"] captura com elegância o que Viveiros de Castro (1996) chamou de perspectivismo cosmológico, ou multinaturalismo: o que distingue os diferentes tipos de gente são seus corpos, não suas culturas. Deve-se notar, entretanto, que esse exemplo de cosmologia perspectivista não foi obtido no curso de uma discussão esotérica sobre o mundo oculto dos espíritos, mas em uma conversação em torno de preocupações eminentemente práticas: o que causa a diarréia infantil? Seria tentador ver as posições da professora e da mulher piro como representando duas cosmologias distintas, o multiculturalismo e o multinaturalismo, e imaginar a conversa como um choque de cosmologias ou culturas. Isto seria, penso, um engano. As duas cosmologias/culturas, no caso, estão em contato já há muito tempo, sua imbricação precede de muito os processos ontogenéticos através dos quais a professora e essa mulher piro vieram a formulá-las como auto-evidentes. M as sobretudo, tal interpretação estaria traduzindo o diálogo nos termos gerais de uma de suas partes, a saber, o multiculturalismo. As coordenadas da posição da mulher piro estariam sendo sistematicamente violadas pela análise. Isso não quer dizer, é claro, que eu creia que as crianças devem beber água não-fervida. M as isso quer dizer que a análise etnográfica não pode ir adiante se já se decidiu de antemão o sentido geral de um encontro como esse".
\end{abstract}

Concordo com muito do argumento acima. A anedota reportada por Gow é de fato uma esplêndida ilustração, especialmente por derivar de um incidente banalmente cotidiano, da divergência irredutível entre o que chamei de "multiculturalismo" e de "multinaturalismo". M as a análise sugerida por ele não me parece a única possível. Assim, sobre a questão da tradução da conversa nos termos gerais de uma das partes - no caso, a professora: não seria igualmente possível, e sobretudo necessário, traduzi-la nos termos gerais da outra parte? Pois não há terceira posição, uma posição absoluta de sobrevôo que mostrasse o caráter relativo das duas outras. É preciso tomar partido. 
Será que se poderia dizer, por exemplo, que cada mulher está 'culturalizando' a outra nessa conversa, isto é, atribuindo a tolice da outra à 'cultura' desta, ao passo que 'interpreta' a sua própria posição como 'natural'? Seria o caso de se dizer que o argumento sobre o 'corpo' avançado pela mulher piro já é uma espécie de concessão aos pressupostos da professora? Talvez; mas não houve concessão recíproca. A mulher piro concordou em discordar, mas a professora, de modo al gum. A primeira não contestou o fato de que as pessoas da cidade de Lima ("talvez") devam beber água fervida, ao passo que a segunda recusou peremptoriamente a idéia de que as pessoas da aldeia de Santa Clara não o devam.

O 'relativismo' da mulher piro - um relativismo 'natural', não 'cultural', note-se - poderia ser interpretado segundo certas hipóteses a respeito da economia cognitiva das sociedades não-modernas, ou sem escrita, ou tradicionais etc. Nos termos da teoria de Robin Horton (1993:379-ss.), por exemplo. Horton diagnostica o que chamou de "paroquialismo de visão de mundo" (world-view parochialism) como algo característico dessas sociedades: contrariamente à exigência implícita de universal ização contida nas cosmologias racionalizadas da modernidade ocidental, as cosmologias dos povos tradicionais parecem marcadas por um espírito de grande tolerância, mas que é na verdade uma indiferença à concorrência de visões de mundo discrepantes. O relativismo aparente dos Piro não manifestaria, assim, sua largueza de vistas, mas, muito ao contrário, sua miopia: eles pouco se importam como as coisas são alhures32.

Há vários motivos para se recusar uma leitura como essa de Horton; entre outros, o de que o dito relativismo primitivo não é apenas intercultural, mas intracultural e 'autocultural', e que ele não exprime nem tolerância, nem indiferença, mas sim exterioridade absoluta à idéia criptoteológica de 'cultura' como conjunto de crenças (Tooker 1992; Viveiros de Castro 1993). O motivo principal, entretanto, está perfeitamente prefigurado nos comentários de Gow, a saber, que essa idéia do "paroquialismo" traduz o debate de Santa Clara nos termos da posição da professora, com seu universalismo natural e seu diferencialismo (mais ou menos tolerante) cultural. Há várias visões de mundo, mas há um só mundo - um mundo onde todas as crianças devem beber água fervida (se, é claro, se encontrarem em uma parte do mesmo onde a diarréia infantil seja uma ameaça).

Em lugar dessa leitura, proponho uma outra. A anedota dos corpos diferentes convida a um esforço de determinação do mundo possível expresso no juízo da mulher piro. Um mundo possível no qual os corpos humanos sejam diferentes em Lima e em Santa Clara - no qual seja 
necessário que os corpos dos brancos e dos índios sejam diferentes. Ora, determinar esse mundo não é inventar um mundo imaginário, um mundo dotado, digamos, de outra física ou outra biologia, onde o universo não seria isotrópico e os corpos se comportariam segundo leis diferentes em lugares distintos. Isso seria (má) ficção científica. O que se trata é de encontrar o problema real que torna possível o mundo implicado na réplica da mulher piro. O argumento de que "nossos corpos são diferentes" não exprime uma teoria biológica alternativa, e, naturalmente, equivocada, ou uma biologia objetiva imaginariamente não-standard 33 . O que o argumento piro manifesta é uma idéia não-biológica de corpo, idéia que faz com que questões como a diarréia infantil não sejam tratadas enquanto objetos de uma teoria biológica. O argumento afirma que nossos 'corpos' respectivos são diferentes, entenda-se, que os conceitos piro e ocidental de corpo são divergentes, não que nossas 'biologias' são diversas. A anedota da água piro não reflete uma outra visão de um mesmo corpo, mas um outro conceito de corpo, cuja dissonância subjacente à sua 'homonímia' com o nosso é, justamente, o problema. Assim, por exemplo, o conceito piro de corpo pode não estar, tal o nosso, na alma, isto é, na 'mente', sob o modo de uma representação de um corpo fora dela; ele pode estar, ao contrário, inscrito no próprio corpo como perspectiva (Viveiros de Castro 1996). Não, então, o conceito como representação de um corpo extraconceitual, mas o corpo como perspectiva interna do conceito: o corpo como implicado no conceito de perspectiva. E se, como dizia Spinoza, não sabemos o que pode um corpo, quanto menos saberíamos o que pode esse corpo. Para não falar de sua alma.

Recebido em 15 de janeiro de 2002

A provado em 18 de fevereiro de 2002

Eduardo Viveiros de Castro é professor de etnologia no Museu Nacional/ UFRJ, e membro da Equipe de Recherche en Ethnologie Amérindienne (Paris). 


\section{Notas}

1 O fato de o discurso do antropólogo consistir canônica e literalmente em um texto tem muitas implicações, que não cabe desenvolver aqui. Elas foram objeto de atenção exaustiva por parte de correntes recentes de reflexão auto-antropológica. O mesmo se diga do fato de o discurso do nativo não ser, geralmente, um texto, e do fato de ele ser freqüentemente tratado como se o fosse.

2 “O conhecimento não é uma conexão entre uma substância-sujeito e uma substância-objeto, mas uma relação entre duas relações, das quais uma está no domínio do objeto, e a outra no domínio do sujeito; [... ] a relação entre duas relações é ela própria uma relação" (Simondon 1995:81, ênfases removidas). Traduzi por 'conexão' a palavra rapport, que Gilbert Simondon distingue de relation, 'reIação': "podemos chamar de relação a disposição dos elementos de um sistema que está além de uma simples visada arbitrária do espírito, e reservar o termo conexão para uma relação arbitrária e fortuita [...] a relação seria uma conexão tão real e importante como os próprios termos; poder-se-ia dizer, por conseguinte, que uma verdadeira relação entre dois termos equivale, de fato, a uma conexão entre três termos" (Simondon 1995:66).

3 Veja-se M. Strathern (1987), para uma análise dos pressupostos relacionais desse efeito de conhecimento. A autora argumenta que a relação do nativo com seu discurso não é, em princípio, a mesma que a do antropólogo com o seu, e que tal diferença ao mesmo tempo condiciona a relação entre os dois discursos e impõe limites a toda empresa de auto-antropologia.

4 Somos todos nativos, mas ninguém é nativo o tempo todo. Como recorda Lambek (1998:113) em um comentário à noção de habitus e congêneres, “as práticas encorporadas são realizadas por agentes capazes também de pensar contemplativamente: nada do que 'não é preciso dizer' [goes without saying] permanece não-dito para sempre". Pensar contemplativamente, sublinhe-se, não significa pensar como pensam os antropólogos: as técnicas de reflexão variam crucialmente. A antropologia reversa do nativo (o cargo cult melanésio, por exemplo; Wagner 1981:31-34) não é a auto-antropologia do antropólogo (Strathern 1987:3031): uma antropologia simétrica feita do interior da tradição que gerou a antropologia não é simétrica a uma antropologia simétrica feita fora dela. A simetria não cancela a diferença, pois a reciprocidade virtual de perspectivas em que se pensa aqui não é nenhuma 'fusão de horizontes'. Em suma, somos todos antropólogos, mas ninguém é antropólogo do mesmo jeito: “está muito bem que Giddens afirme que 'todos os atores sociais [... ] são teóricos sociais', mas a frase é vazia se as técnicas de teorização têm pouca coisa em comum" (Strathern 1987:30-31).

5 Via de regra, supõe-se que o nativo faz, sem saber o que faz, as duas coisas - a raciocinação natural e a racionalização cultural - , em fases, registros ou situações diferentes de sua vida. As ilusões do nativo são, acrescente-se, tidas por 
necessárias, no duplo sentido de inevitáveis e úteis (são, dirão outros, evolucionariamente adaptativas). É tal necessidade que define o 'nativo', e o distingue do 'antropólogo': este pode errar, mas aquele precisa iludir-se.

6 A 'implausibilidade' é uma acusação freqüentemente levantada pelos praticantes do jogo clássico contra os que preferem outras regras. M as essa noção pertence às salas de interrogatório policial: é lá que devemos tomar o máximo cuidado para que nossas histórias sejam 'plausíveis'.

7 É assim que interpreto a declaração de Wagner (1981:35): “Estudamos a cultura através da cultura, e portanto as operações, sejam quais forem, que caracterizam nossa investigação devem ser também propriedades gerais da cultura."

8 Ver, sobre isso, J ullien (1989:312). Os problemas reais de outras culturas são problemas apenas possíveis para a nossa; o papel da antropologia é o de dar a essa possibilidade (lógica) o estatuto de virtualidade (ontológica), determinando - ou seja, construindo - sua operação latente em nossa própria cultura.

9 Publicado em apêndice à Logique du Sens (Deleuze 1969a:350-372; ver também Deleuze 1969b:333-335, 360). Ele é retomado, em termos praticamente idênticos, em seu quase-último texto, Qu'est-ce que la Philosophie? (Deleuze e Guattari 1991:21-24, 49).

10 “[O]utrem para mim introduz o signo do não-percebido naquilo que percebo, determinando-me a apreender o que não percebo como perceptível para outrem" (Deleuze 1969a:355).

11 Esse 'ele' que é Outrem não é uma pessoa, uma terceira pessoa diversa do eu e do tu, à espera de sua vez no diálogo, mas também não é uma coisa, um 'isso' de que se fala. Outrem seria mais bem a "quarta pessoa do singular" - situada, digamos assim, na terceira margem do rio - , anterior ao jogo perspectivo dos pronomes pessoais (Deleuze 1995:79).

12 Que faria o que pensa porque a bifurcação de sua natureza, ainda que admitida por uma questão de princípio, distingue, na pessoa do antropólogo, o 'antropólogo' do 'nativo', e portanto vê-se expulsa de campo antes do jogo. A expressão “bifurcação da natureza” é de Whitehead (1964: cap. II); ela protesta contra a divisão do real em qualidades primárias, inerentes ao objeto, e qualidades secundárias, atribuídas ao objeto pelo sujeito. As primeiras são a meta própria da ciência, mas ao mesmo tempo seriam, em última instância, inacessíveis; as segundas são subjetivas e, em última instância, ilusórias. Isto produz duas naturezas, “das quais uma seria conjetura e a outra, sonho" (Whitehead 1964:30; ver a citação e seu comentário em Latour 1999:62-76, 315 n. 49 e n. 58). Tal bifurcação é a mesma presente na oposição antropológica entre natureza e cultura. E quando o objeto é ao mesmo tempo um sujeito, como no caso do nativo, a bifurcação de sua natureza transforma-se na distinção entre a conjetura do antropólogo e o sonho do nativo: cognição vs. ideologia (Bloch), teoria primária vs. secundária 
(Horton), modelo inconsciente vs. consciente (Lévi-Strauss), representações proposicionais vs. semiproposicionais (Sperber), e assim por diante.

13 Ver M. Strathern (1999b:172), sobre os termos da relação possível de conhecimento entre, por exemplo, os antropólogos ocidentais e os melanésios: “Isto nada tem a ver com compreensão, ou com estruturas cognitivas; não se trata de saber se eu posso entender um melanésio, se posso interagir com ele, comportar-me adequadamente etc. Estas coisas não são problemáticas. O problema começa quando começamos a produzir descrições do mundo".

${ }^{14}$ A ponderação é de Alfred Gell (1998:4); ela poderia, é claro, aplicar-se igualmente à 'natureza humana'.

15 Esse argumento é apenas aparentemente semelhante ao que Sperber (1982: cap. 2) avança contra o relativismo. Pois esse autor não crê que a diversidade cultural seja um problema político-epistemológico irredutível. Para ele, as culturas são exemplares contingentes de uma mesma natureza humana substantiva. O máximo de Sperber é um denominador comum, jamais um múltiplo — ver a crítica de Ingold (2000:164) a Sperber, feita de outro ponto de vista, mas compatível com o aqui adotado.

16 Sobre estas duas idéias de limite, uma de origem platônica e euclidiana, a outra de origem arquimediana e estóica (que reaparece no cálculo infinitesimal do século XVII), ver Deleuze (1981).

17 Ver, no mesmo sentido, a densa argumentação fenomenológica de Mimica (1991:34-38).

18 Veyne parafraseia inadvertidamente Evans-Pritchard, ao escrever, sobre essa condição (universal) de prisioneiro de um bocal histórico (particular), que "quando não se vê o que não se vê, não se vê sequer que não se vê" (Veyne 1983:127, ênfases minhas, para maior clareza).

19 Estou aqui, obviamente, interpretando o ensaio de Veyne com um tanto de má vontade. Ele é bem mais rico (porque mais ambíguo) do que isso, extravasando o bocal da infeliz imagem do 'bocal'.

20 Essa leitura da noção de Gedankenexperiment é aplicada por T. M archaisse à obra de F. J ullien sobre o pensamento chinês (J ullien e Marchaisse 2000:71). Ver também J ullien (1989:311-312), sobre as 'ficções' comparativas.

21 Respondendo aos críticos de sua análise da socialidade melanésia, que a acusam de negar a existência de uma 'natureza humana' inclusiva dos povos daquela região, M arilyn Strathern (1999b:172) esclareceu: “[A ] diferença que existe está no fato de que os modos pelos quais os melanésios descrevem, dão conta da natureza humana, são radicalmente diferentes dos nossos - e o ponto é que só temos acesso a descrições e explicações, só podemos trabalhar com isso. Não há 
meio de eludir essa diferença. Então, não se pode dizer: muito bem, agora entendi, é só uma questão de descrições diferentes, então passemos aos pontos em comum entre nós e eles... pois a partir do momento em que entramos em comunicação, nós o fazemos através dessas autodescrições. É essencial dar-se conta disso" . O ponto, com efeito, é essencial. Ver também o que diz F. J ullien, sobre a diferença entre se afirmar a existência de diferentes "modos de orientação no pensamento" e se afirmar a operação de “outras lógicas” (J ullien e M archaisse 2000:205-207).

22 Sobre a 'assinatura' das idéias filosóficas e científicas e o 'batismo' dos conceitos, ver Deleuze e Guattari (1991:13, 28-29).

23 A citação, e o parágrafo que a precede, foram canibalizados de Viveiros de Castro (1999:153).

24 Sobre a 'não-filosofia' — o plano de imanência ou a vida —, ver Deleuze e Guattari (1991:43-44, 89, 105, 205-206), bem como o brilhante comentário de Prado J r. (1998).

25 A expressão "aparentemente irracional" é um clichê secular da antropologia, de Andrew Lang em 1883 (cf. Detienne 1981:28) a Dan Sperber em 1982.

26 Como professam as que poderíamos chamar "antropologias do bom senso" , no duplo sentido do genitivo, como a de Obeyesekere (1992) contra Sahlins e a de LiPuma (1998) contra Strathern.

${ }^{27}$ As observações de Wittgenstein sobre o Golden Bough permanecem, a esse título, completamente pertinentes. Entre outras: “Um símbolo religioso não se funda sobre nenhuma opinião. E é somente em relação à opinião que se pode falar em erro"; “Creio que o que caracteriza o homem primitivo é que ele não age a partir de opiniões (ao contrário, Frazer)"; "O absurdo consiste aqui no fato de que Frazer apresenta tais idéias [sobre os ritos da chuva etc.] como se esses povos tivessem uma representação completamente falsa (e mesmo insensata) do curso da natureza, quando eles possuem apenas uma interpretação estranha dos fenômenos. Isto é, se eles pusessem por escrito seu conhecimento da natureza, ele não se distinguiria fundamentalmente do nosso. A penas sua magia é outra" (Wittgenstein 1982:15, 24, 27). Sua magia, ou, poderíamos dizer, seus conceitos.

${ }^{28}$ A exteriorização dessa condição especial e artificial, isto é, sua generalização e naturalização, gera o equívoco clássico da antropologia: a eternidade formal do possível é fantasmada sob o modo de uma não-contemporaneidade histórica entre o antropólogo e o nativo - tem-se então a primitivização de Outrem, seu congelamento como objeto (do) passado absoluto.

29 A lexiades cita seu interlocutor em espanhol - "Todos los animales son Ese Eja”. N ote-se já aqui uma torção: 'todos' os animais (o etnógrafo mostra que há numerosas exceções) não são 'humanos', e sim 'Ese Eja', etnônimo que pode ser traduzido como 'pessoas humanas', em oposição a ‘espíritos' e a 'estrangeiros'. 
$30 \mathrm{~N}$ ão estou aqui me referindo ao problema da aquisição ontogenética de 'conceitos' ou 'categorias', no sentido que a psicologia cognitiva dá a estas palavras. A simultaneidade das idéias de pecari, humano e de sua identidade (condicional e contextual) é, do ponto de vista empírico, uma característica do pensamento dos adultos dessa cultura. Ainda que se admitisse que as crianças começam por adquirir ou manifestar os 'conceitos' de pecari e de humano antes de serem ensinadas que "os pecaris são humanos", resta que os adultos, quando agem ou argumentam com base nesta idéia, não reencenam em suas cabeças tal suposta seqüência cronológica, primeiro pensando nos humanos e nos pecaris, depois em sua associação. Além disso e sobretudo, tal simultaneidade não é empírica, mas transcendental: ela significa que a humanidade dos pecaris é um componente a priori da idéia de pecari (e da idéia de humano).

31 "As noções de importância, de necessidade, de interesse são mil vezes mais determinantes que a noção de verdade. Não, de forma alguma, porque elas a substituam, mas porque medem a verdade do que digo" (Deleuze 1990:177, ênfases minhas).

32 E com efeito, a réplica da mulher piro é idêntica a uma observação dos Zande, consignada no livro que é a bíblia dos antropólogos da persuasão de Horton: “Uma vez, ouvi um zande dizer de nós: 'Talvez lá no país deles as pessoas não sejam assassinadas por bruxos, mas aqui elas são" (Evans-Pritchard 1978:274). Agradeço a Ingrid Weber a lembrança.

33 Como advertia Gell (1998:101) em um contexto semelhante, a magia não é uma física equivocada, mas uma 'meta-física': “O engano de Frazer foi, por assim dizer, o de imaginar que os praticantes da magia dispunham de uma teoria física não-standard, quando, na verdade, 'magia' é aquilo que se tem quando se dispensa uma teoria física em vista de sua redundância, e quando se busca apoio na idéia, em si mesma perfeitamente praticável, de que a explicação de qualquer evento dado [... e é que ele é causado intencionalmente". 


\section{Referências bibliográficas}

ALEXIADES, M iguel. 1999. Ethnobotany of the Ese Eja: Plants, Health, and Change in an A mazonian Society. Tese de Doutorado, City University of New York.

CLASTRES, Pierre. 1974 [1962]. “Échange et Pouvoir: Philosophie de la Chefferie Indienne". In: La Société contre I'État: Recherches d'Anthropologie Politique. Paris: M inuit. pp. 25-42.

DELEUZE, Gilles. 1969a. Logique du Sens. Paris: Minuit.

_ . 1969b. Différence et Répétition. Paris: PUF.

.1981. Aula sobre Spinoza, 17 de fevereiro.

_ . 1990. Pourparlers. Paris: M inuit. 1995 [1979]. Dialogues. Paris: Flammarion.

e GUATTARI, Félix. 1991. Qu'est-ce que la Philosophie? Paris: Minuit.

DETIENNE, Marcel. 1981. L'Invention de la Mythologie. Paris: Gallimard.

EVANS-PRITCHARD, Edward. 1978 [1937]. Bruxaria, Oráculos e M agia entre os Azande (edição resumida por Eva Gillies). Rio de J aneiro: Zahar Editores (trad. E. Viveiros de Castro).

GELL, Alfred. 1998. Art and Agency: An Anthropological Theory. Oxford: Clarendon.

. 1999. The Art of Anthropology: Essays and Diagrams. London: Athlone. HORTON, Robin. 1993. Patterns of Thought in Africa and the West: Essays on Magic, Religion and Science. Cambridge: Cambridge University Press.

INGOLD, Tim. 1992. "Editorial". Man, 27(1):694-697. .2000. The Perception of the Environment. Essays on Livelihood,
Dwelling and Skill. London: Routledge.

JULLIEN, François. 1989. Procès ou Création: Une Introduction à la Pensée Chinoise. Paris: Seuil. e MARCHAISSE, Thierry. 2000. Penser d'un Dehors (la Chine). Entretiens d'Extrême Occident. Paris: Seuil.

LAMBEK, Michael. 1998. "Body and $M$ ind in $M$ ind, Body and $M$ ind in Body: Some Anthropological Interventions in a Long Conversation". In: A. Strathern e M. Lambek (orgs.), Bodies and Persons: Comparative Perspectives from Africa and M elanesia. Cambridge: Cambridge University Press. pp. 103-122.

LATOUR, Bruno. 1991. Nous n'Avons J amais Été Modernes. Paris: Découverte. . 1996a. "Not the Question". Anthropology N ewsletter, 37(3):1-5.

. 1996b. Petite Refléxion sur le Culte M oderne des Dieux Faîtiches. Le Plessis/Robinson: Institut Synthélabo.

.1999. Politiques de la Nature: Comment Faire entrer les Sciences en Démocratie. Paris: Découverte.

LÉVI-STRAUSS, Claude. 1962. La Pensée Sauvage. Paris: Plon.

. 1971. L'Homme Nu. Paris: Plon.

LIPUM A, Edward. 1998. “M odernity and Forms of Personhood in Melanesia". In: A. Strathern e M . Lambek (orgs.), Bodies and Persons: Comparative Perspectives from Africa and M elanesia. Cambridge: Cambridge University Press. pp. 53-79.

MIMICA, J adran. 1991. "The Incest Passions: An Outline of the Logic of Iqwaye Social Organization (part 1)". Oceania, 62(1):34-58. 
MOORE, Henrietta. 1999. “Anthropological Theory at the Turn of the Century". In: H. Moore (org.), Anthropological Theory Today. London: Polity Press. pp. 1-23.

OBEYESEKERE, Gananath. 1992. The A potheosis of Captain Cook: European Mythmaking in the Pacific. Princeton: Princeton University Press. PRADO J R., Bento. 1998. "Sur le ‘Plan d'Immanence'”. In: E. Alliez (org.), Gilles Deleuze: Une Vie Philosophique. Le Plessis/Robinson: Institut Synthélabo. pp. 305-324.

SCHOLTE, Bob. 1984. "Reason and Culture: The Universal and the Particular Revisited". American Anthropologist, 86(4):960-965.

SCHREMPP, Gregory. 1992. Magical Arrows: The Maori, the Greeks, and the Folklore of the Universe. Madison: University of Wisconsin Press.

SIM ONDON, Gilbert. 1995 [1964]. L'Individu et sa Genèse Physico-Biologique. Paris: Millon.

SPERBER, Dan. 1974. Le Symbolisme en Général. Paris: Hermann. . 1982. Le Savoir des Anthropologues. Paris: Hermann.

STRATHERN, Marilyn. 1987. "The Limits of Auto-A nthropology". In: A. Jackson (org.), Anthropology at Home. London: Tavistock. pp. 16-37. . 1988. The Gender of the Gift: Problems with Women and Problems with Society in Melanesia. Berkeley: University of California Press. .1999a. Property, Substance and Effect: Anthropological Essays on Persons and Things. London: Athlone. . 1999b. "No Limite de uma Certa Linguagem: Entrevista com M arilyn Strathern". Mana, 5(2):157-175.
TOOKER, Deborah. 1992. “Identity Systems of Highland Burma: 'Belief', A kha zan, and a Critique of Interiorized Notions of Ethno-Religious Identity". Man, 27(4):799-819.

VERNANT, J ean-Pierre. 1996 [1966]. "Raisons d'Hier et d'Aujourdh'ui". In: Entre Mythe et Politique. Paris: Seuil. pp. 229-236.

VEYNE, Paul. 1983. Les Grecs Out-Ils Cru à Leurs Mythes? Paris: Seuil.

VIVEIROS DE CASTRO, Eduardo. 1993. “Le M arbre et le M yrte: De I'Inconstance de I'Âme Sauvage". In: A. Becquelin e A. Molinié (orgs.), Mémoire de la Tradition. Nanterre: Société d'Ethnologie. pp. 365-431. . 1996. “Os Pronomes Cosmológicos e o Perspectivismo Ameríndio". Mana, 2(2):115-144.

. 1999. “Etnologia Brasileira”. In: S. Miceli (org.), O que Ler na Ciência Social Brasileira (1970-1995) - Volume I: A ntropologia. São Paulo: Ed. Sumaré/ANPOCS. pp. 109-223.

WAGNER, Roy. 1981. The Invention of

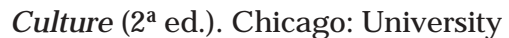
of Chicago Press.

.1986. Symbols than Stand for Themselves. Chicago: University of Chicago Press.

WHITEHEAD, Alfred N. 1964 [1920]. Concept of Nature. Cambridge: Cambridge University Press.

WHITEHOUSE, Harvey. 2000. Arguments and I cons: Divergent M odes of Religiosity. Oxford: Oxford University Press.

WITTGENSTEIN, Ludwig. 1982 [193048]. Remarques sur le Rameau d'Or de Frazer. Paris: L'Age d'Homme (trad. J. Bouveresse). 
Resumo

Este artigo tenta extrair as implicações teóricas do fato de que a antropologia não apenas estuda relações, mas que o conhecimento assim produzido é ele próprio uma relação. Propõe-se, assim, uma imagem da atividade antropológica como fundada no pressuposto de que os procedimentos característicos da disciplina são conceitualmente de mesma ordem que os procedimentos investigados. Entre tais implicações, está a recusa da noção corrente de que cada cultura ou sociedade encarna uma solução específica de um problema genérico, preenchendo uma forma universal (o conceito antropológico) com um conteúdo particular (as concepções nativas). A o contrário, a imagem aqui proposta sugere que os problemas eles mesmos são radicalmente diversos, e que o antropólogo não sabe de antemão quais são eles.

Palavras-chave Conhecimento Antropológico, Imaginação Conceitual, Cultura, Relação, Perspectivismo
Abstract

This article attempts to extract the theoretical implications arising from the fact that anthropology not only studies relations, but that the knowledge it produces in the process is itself a relation. It therefore proposes an image of anthropology as an activity founded on the premise that the procedures characteristic of the discipline are conceptually of the same order as those it investigates. Among these implications is the rejection of the contemporary notion that each culture or society embodies a specific solution to a generic problem, filling a universal form (the anthropological concept) with a particular content (the native conceptions). Much the opposite: the image proposed here suggests that the problems themselves are radically heterogenic, and that the anthropologist cannot know beforehand what these will be.

Key words Anthropological Knowledge, Conceptual Imagination, Culture, Relation; Perspectivism 